\title{
Prevalensi Kejadian Penyakit Kulit pada Anjing di My Vets Animal Clinic Bumi Serpong Damai Tahun 2016
}

\author{
Tri Ayu Kristianty*, Zella Nofitri Efendi, Fathia Ramadhani \\ My Vets Animal Clinic BSD, Jalan Kalimantan Blok F2 No. 32 Bumi Serpong Damai, Tangerang Selatan
}

ABSTRAK: Pyoderma adalah dermatitis yang disebabkan oleh infeksi bakteri dan merupakan penyakit kulit yang umum terjadi pada anjing. Pyoderma pada anjing terjadi sekitar 55\% dari kasus kulit yang datang ke My Vets Bumi Serpong Damai (BSD) pada tahun 2016. Malassezia spp. adalah commensal yeast yang umum ditemukan pada kulit dan mukosa anjing. Infeksi Malassezia terjadi sekitar 43\% dari kasus kulit yang datang ke My Vets BSD pada tahun 2016. Infestasi parasit pada kulit anjing yang umum terjadi disebabkan oleh mites dan serangga. Infestasi parasit pada anjing terjadi sekitar 9\% dari kasus kulit yang datang ke My Vets BSD dengan parasit yang paling umum adalah Demodex spp. Breed anjing yang paling sering terkena penyakit kulit dari keseluruhan anjing yang datang ke My Vets BSD di antaranya adalah Beagle dengan jumlah sekitar 11\%, Shih Tzu dengan jumlah sekitar 11\%, dan Mongrel dengan jumlah sekitar 16\%. Berdasarkan data tersebut, kasus kulit yang paling banyak terjadi dibandingkan dengan kasus kulit lain di My Vets BSD pada periode tahun 2016 adalah pyoderma dan anjing yang paling sering terkena penyakit kulit adalah Mongrel.

Kata kunci:

breed, demodex, malassezia, pyoderma

\section{- PENDAHULUAN}

Pyoderma adalah dermatitis yang disebabkan oleh infeksi bakteri dan merupakan penyakit kulit yang umum terjadi pada anjing. Berdasarkan kedalaman kulit yang terlibat, pyoderma bisa diklasifikasikan sebagai surface, superficial, dan deep. Kondisi ini hampir selalu merupakan sekunder dari gangguan lain yang terjadi pada tubuh.

Malassezia spp. adalah commensal yeast yang umum ditemukan pada kulit dan mukosa anjing. Yeast ini cenderung memilih muncul pada area lembap, berminyak pada tubuh, umumnya menyebabkan erythema dan hiperplasia epidermal dengan produksi sebum berlebih. Pertumbuhan Malassezia pada kuping menyebabkan otitis berserumen yang tipikal dengan erythema dan, pada banyak kasus, hiperplasia pada saluran telinga luar.

Infestasi parasit pada kulit anjing yang umum terjadi disebabkan oleh mites dan serangga. Lesi pada kulit akibat serangga yang paling umum terjadi pada anjing adalah infestasi larva lalat (myiasis). Beberapa mites penting yang menginfestasi anjing adalah Demodex spp, Sarcoptes scabiei var. canis, dan Otodectes cynotis (Goth 2014).

\section{- HASIL DAN PEMBAHASAN}

Pemeriksaan sampel kulit menggunakan Scotch Tape yang dilakukan pada pasien-pasien dengan keluhan pada kulit menunjukkan hasil di antaranya adanya neutrofil, bakteri kokus, Malassezia spp, dan Demodex spp. Masing-masing sampel dapat berisi neutrofil dan bakteri kokus atau neutrofil, bakteri kokus, dan Malassezia spp. atau Malassezia spp. atau Demodex spp. dan Malassezia spp atau Demodex spp.
Tabel 1 menunjukkan prevalensi kejadian penyakit kulit pada pasien anjing di My Vets Animal Clinic BSD tahun 2016. Hasil ini menunjukkan satu anjing dapat mengalami lebih dari satu penyakit kulit yang ada. Pyoderma pada anjing terjadi sejumlah 55\% dari kasus kulit yang datang ke My Vets Animal Clinic BSD pada periode tahun 2016, infeksi Malassezia spp. terjadi sejumlah 43\%, dan infestasi parasit terjadi sejumlah $9 \%$ dengan parasit yang paling umum adalah Demodex spp.

Tabel 1 Persentase hasil pemeriksaan Scotch Tape

\begin{tabular}{cc}
\hline Hasil pemeriksaan Scotch Tape & Persentase \\
\hline Neutrofil, bakteri kokus & $55 \%$ \\
Malassezia spp. & $43 \%$ \\
Demodex spp. & $9 \%$ \\
\hline
\end{tabular}

Breed anjing yang paling sering terkena penyakit kulit dari keseluruhan anjing yang datang ke My Vets BSD di antaranya adalah Beagle dengan jumlah sekitar $11 \%$, Shih Tzu dengan jumlah sekitar 11\%, dan Mongrel dengan jumlah sekitar 16\% (Tabel 2). Terdapat berbagai macam faktor yang bisa menyebabkan seekor anjing terkena penyakit kulit. Pengamatan pada tahun 2016 di My Vets Animal Clinic BSD menunjukkan tiga breed anjing teratas yang

$\begin{array}{ll}\text { Diterima } & : 21 \text { Juli } 2017 \\ \text { Direvisi } & : 8 \text { Agustus } 2017 \\ \text { Disetujui } & : 11 \text { Agustus } 2017\end{array}$


paling sering terkena penyakit kulit adalah Beagle, Shih Tzu, dan Mongrel. Hal ini mungkin disebabkan oleh lipatan kulit atau panjang rambut sehingga mereka lebih rawan terhadap penyakit kulit. Selain itu, faktor-faktor lain seperti kelembapan lingkungan, kebersihan manusia yang merawat, maupun daya tahan setiap individu mempengaruhi tingkat kejadian yang ada (Doerr 2015, Puja 2014).

Tabel 2 Persentase breed anjing dengan penyakit kulit

\begin{tabular}{cc}
\hline Breed anjing & Persentase \\
\hline Beagle & $11 \%$ \\
Shih Tzu & $11 \%$ \\
Mongrel & $16 \%$ \\
\hline
\end{tabular}

\section{- SIMPULAN}

Kasus penyakit kulit yang paling banyak terjadi di My Vets BSD pada periode tahun 2016 adalah pyoderma dan anjing yang paling sering terkena penyakit kulit adalah Mongrel.

\section{- INFORMASI PENULIS}

Penulis untuk Korespondensi

felix_ayu@yahoo.com

\section{Persetujuan Penulis}

Seluruh penulis telah memberikan persetujuan terhadap versi final naskah ini.

\section{- PUSTAKA ACUAN}

Doerr K. 2015. Malassezia dermatitis and otitis in dogs. Veterinary Focus 25(2): 19-25.

Goth GM. 2014. Canine and Feline Dermatology Atlas. Zaragoza (SP): Servet.

Puja IK. 2014. Efektivitas ivermectin dengan kombinasi amitraz untuk pengobatan infestasi demodekosis alami pada anjing. Prosiding Konferensi Ilmiah Veteriner Nasional (KIVNAS) Perhimpunan Dokter Hewan Indonesia ke-13. Palembang (IND) 2014 